2004 104: 3343-3348

Prepublished online Jul 15, 2004;

doi:10.1182/blood-2004-01-0385

\title{
Atypical marginal zone hyperplasia of mucosa-associated lymphoid tissue: a reactive condition of childhood showing immunoglobulin lambda light-chain restriction
}

Ayoma D. Attygalle, Hongxiang Liu, Sima Shirali, Timothy C. Diss, Christoph Loddenkemper, Harald Stein, Ahmet Dogan, Ming-Qing Du and Peter G. Isaacson

Updated information and services can be found at:

http://bloodjournal.hematologylibrary.org/cgi/content/full/104/10/3343

Articles on similar topics may be found in the following Blood collections:

Immunobiology (3530 articles)

Neoplasia (4075 articles)

Information about reproducing this article in parts or in its entirety may be found online at:

http://bloodjournal.hematologylibrary.org/misc/rights.dt|\#repub_requests

Information about ordering reprints may be found online at:

http://bloodjournal.hematologylibrary.org/misc/rights.dt|\#reprints

Information about subscriptions and ASH membership may be found online at:

http://bloodjournal.hematologylibrary.org/subscriptions/index.dtl

Blood (print ISSN 0006-4971, online ISSN 1528-0020), is published

semimonthly by the American Society of Hematology, 1900 M St, NW, Suite 200, Washington DC 20036.

Copyright 2007 by The American Society of Hematology; all rights reserved.

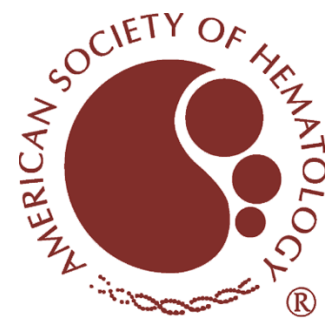




\section{Atypical marginal zone hyperplasia of mucosa-associated lymphoid tissue: a reactive condition of childhood showing immunoglobulin lambda light-chain restriction}

Ayoma D. Attygalle, Hongxiang Liu, Sima Shirali, Timothy C. Diss, Christoph Loddenkemper, Harald Stein, Ahmet Dogan, Ming-Qing Du, and Peter G. Isaacson

Mucosa-associated lymphoid tissue (MALT) lymphomas usually arise at sites of acquired MALT and are uncommon in native MALT (eg, Peyer patches and tonsil). Malignancy in these low-grade lymphomas is often inferred by immunoglobulin light-chain restriction and expression of CD43; molecular genetic evidence is sought only if these are in doubt. We report 6 cases (4 tonsils, 2 appendixes) of marginal zone (MZ) hyperplasia in children aged 3 to 11 years that, despite histologic and immunophenotypic features indicative of lymphoma, were polyclonal by molecular analysis. No lymphoma-directed therapy was given and patients remain alive and well (5 cases, median follow-up 35.3 months). The involved tonsil and appendix showed florid MZ hyperplasia with prominent intraepithelial B cells (IEBCs). The MZ B cells and IEBCs showed a high-proliferation fraction and a $\mathrm{CD}_{20}{ }^{+}, \mathrm{CD}_{21}{ }^{+}, \mathrm{CD}_{2}{ }^{-}$, immunoglobulin (Ig) superfamily receptor translocation-associated 1-positive $\left(\right.$ IRTA-1 $\left.{ }^{+}\right), \mathrm{CD}^{+} 3^{+}$, multiple myeloma oncogene 1 (MUM-1), IgM+ ${ }^{+}$phenotype. Polymerase chain reaction (PCR), cloning, and sequencing of rearranged $\lg \mathrm{H}$ and Ig $\lambda$ genes (whole tissue sections [6 cases]; microdissected cells [2 cases]) showed that the MZ B cells and IEBCs were polyclonal and the IgH genes nonmutated. In contrast, MZ (intraepithelial) B cells of 6 control tonsils had a similar immunophenotype, except for expression of CD27 and polytypic light chains, whereas molecular studies showed that they were polyclonal with mutated Ig genes. (Blood. 2004;104:3343-3348)

๑) 2004 by The American Society of Hematology

\section{Introduction}

Extranodal marginal zone (MZ) B-cell lymphoma of mucosaassociated lymphoid tissue (MALT) lymphoma and nodal MZ lymphoma are related entities believed to be derived from the post-germinal center MZ B cell. ${ }^{1-3}$ Splenic MZ lymphoma, initially mistakenly interpreted as derived from the $\mathrm{MZ},{ }^{4}$ is clinically, morphologically, and immunophenotypically a distinct entity, the cell of origin yet unclear. ${ }^{5-7}$ Morphologically, MALT lymphomas comprise a MZ infiltrate of small B cells, including centrocyte-like cells and monocytoid cells and a small number of transformed blasts that usually form lymphoepithelial lesions. ${ }^{8,9}$ Plasma cell differentiation is present in a proportion of cases. ${ }^{9}$ MALT lymphomas characteristically arise in MALT acquired as a result of inflammatory and/or autoimmune disorders, ${ }^{10}$ such as occurs in gastric mucosa following Helicobacter pylori gastritis ${ }^{11}$ and in the salivary glands as a result of Sjögren syndrome, ${ }^{12}$ and are uncommon at sites of native MALT, such as Peyer patches and, despite a number of reports to the contrary, tonsil. Documentation of MALT lymphomas in children is rare but, notably, a number of cases have been reported in the tonsil. ${ }^{13-17}$ Diagnosis of malignancy in these low-grade lymphomas is based on morphology and immunophenotypic inferences of malignancy and clonality such as anomalous antigen expression (eg, CD43) $)^{18}$ and/or immunoglobulin (Ig) light-chain restriction. ${ }^{19}$ Molecular evidence of clonality is usually sought only in those cases where these properties are in doubt. In this paper we describe a series of 6 cases of florid hyperplasia of the MZ in native MALT (4 in the tonsil and 2 in the appendix) where the morphologic and immunophenotypic features were strongly indicative of lymphoma. However, in none of the cases was this diagnosis supported by molecular genetic studies or clinical follow-up.

\section{Materials and methods}

\section{Tissues}

Six cases (Table 1) with a diagnosis of MZ hyperplasia involving native MALT (4 tonsils and 2 appendixes) occurring in children were retrieved from the consultation archives of the Department of Histopathology, University College London Hospital. Six childhood tonsils showing reactive follicular hyperplasia were used as controls.

\section{Immunohistochemistry}

Paraffin sections $(3 \mu \mathrm{m})$ were immunostained using the streptavidin immunoperoxidase method (ChemMate Streptavidin Peroxidase kit; Dako, Cambridge, United Kingdom) and diaminobenzidine (DAB) chromogen (Dako) following heat-mediated antigen retrieval, as previously described. ${ }^{20}$ Primary antibodies included CD20 (L26; Dako), CD3
From the Department of Histopathology, Royal Free and University College Medical School, London, United Kingdom; Department of Pathology, University of Cambridge, Cambridge, United Kingdom; and Institute of Pathology, Benjamin Franklin University Hospital, Free University Berlin, Berlin, Germany.

Submitted January 30, 2004; accepted June 30, 2004. Prepublished online as Blood First Edition Paper, July 15, 2004; DOI 10.1182/blood-2004-01-0385.

Supported by research grants from the Leukaemia Research Fund and the Pathological Society of Great Britain and Ireland.
Reprints: Peter G. Isaacson, Department of Histopathology, Royal Free and University College Medical School, Rockefeller Bldg, University St, London WC1E 6JJ, United Kingdom; e-mail: p.isaacson@ucl.ac.uk.

The publication costs of this article were defrayed in part by page charge payment. Therefore, and solely to indicate this fact, this article is hereby marked "advertisement" in accordance with 18 U.S.C. section 1734.

(C) 2004 by The American Society of Hematology 
Table 1. Clinical features at presentation and follow-up

\begin{tabular}{|c|c|c|c|}
\hline $\begin{array}{l}\text { Case } \\
\text { no. }\end{array}$ & $\begin{array}{l}\text { Age at } \\
\text { presentation, } \\
\text { y/sex }\end{array}$ & $\begin{array}{c}\text { Clinical information at } \\
\text { presentation }\end{array}$ & $\begin{array}{l}\text { Status at follow-up } \\
\text { (time interval, } \\
\text { mos.) }\end{array}$ \\
\hline 1 & $11 / F$ & $\begin{array}{l}\text { Unilateral (left) tonsillar } \\
\text { enlargement of } 9 \text { months' } \\
\text { duration }\end{array}$ & Alive and well (45) \\
\hline 2 & $3 / \mathrm{M}$ & $\begin{array}{l}\text { Recurrent upper respiratory } \\
\text { infections; no cervical } \\
\text { lymphadenopathy; normal } \\
\text { development; bilateral tonsillar } \\
\text { enlargement }\end{array}$ & Alive and well (41) \\
\hline 3 & $3 / F$ & $\begin{array}{l}\text { Two episodes of tonsillitis; sleep } \\
\text { apnea; massive bilateral } \\
\text { tonsillar enlargement }\end{array}$ & Alive and well (17) \\
\hline 4 & $8 / F$ & $\begin{array}{l}\text { Unilateral tonsillectomy; no other } \\
\text { information available }\end{array}$ & Alive and well (37) \\
\hline 5 & $6 / \mathrm{M}$ & $\begin{array}{l}\text { Abdominal pain and acute } \\
\text { appendicitis }\end{array}$ & Alive and well (43) \\
\hline 6 & $6 / F$ & $\begin{array}{l}\text { Appendectomy; no other } \\
\text { information available }\end{array}$ & Not available \\
\hline
\end{tabular}

(monoclonal anti-CD3; Dako), CD21 (1F8; Dako), CD43 (MT-1; Novocastra, Newcastle, United Kingdom), B-cell lymphoma 2 (BCL-2; 124; Dako), CD10 (56C6; Novocastra), multiple myeloma oncogene 1/interferon regulatory factor 4 (MUM-1/IRF4; MUM-1p; B. Falini, Univeristy of Perugia, Italy), IgM (polyclonal anti-IgM; Dako), IgD (polyclonal anti-IgD; Dako), IgA (polyclonal anti-IgA; Dako), IgG (polyclonal anti-IgG; Dako), CD27 (137B4; Novocastra), Ig superfamily receptor translocation-associated 1 (IRTA-1; M-IRTA-1; Falini), Ki 67 (MIB-1; Dako), к (polyclonal antikappa; Dako), and $\lambda$ (polyclonal antilambda; Dako). Sequential double-staining was performed using CD3/CD43. The first antibody was revealed with peroxidase and the second with alkaline phosphatase with a fast-blue chromogen (Fast Blue/Naphthol; AS-BI; Sigma, Poole, United Kingdom). ${ }^{21}$

\section{Microdissection and DNA extraction}

In cases 2 and 3, the MZ and intraepithelial B cells (IEBCs) were separately microdissected from hematoxylin and eosin-stained sections as described previously. ${ }^{22}$ The IEBCs in a reactive tonsil were similarly microdissected and used as a control. DNA was extracted from the above microdissected cells and whole sections of paraffin-embedded tissues in each case as described previously. 22

\section{Polymerase chain reaction (PCR) analysis of the rearranged Ig genes}

DNA samples prepared from whole tissue sections and microdissected cells were subjected to PCR-based clonality analysis of the rearranged Ig heavy-chain (H) gene (FR2-JH, FR3-JH, and DH-JH), IgK (FR3-JK), and $\operatorname{Ig} \lambda$ light-chain genes (FR3-J $\lambda$ ) using BIOMED-2 primer sets under standardized conditions. ${ }^{23}$ Monoclonal, polyclonal, and negative controls were run in parallel with test samples in all experiments. Products were analyzed on $6 \%$ to $8 \%$ polyacrylamide minigels following heat denaturation and rapid cooling (heteroduplex analysis) according to the BIOMED-2 protocol. ${ }^{23}$ DNA quality was assessed using the BIOMED-2 control gene primer set, which amplifies 100-, 200-, 300-, and 400-bp fragments (the 600-bp primer pair was omitted). ${ }^{23}$

\section{Cloning and sequencing of PCR products}

To study somatic mutation of the rearranged Ig genes, FR2-JH PCR products obtained from microdissected samples were cloned and sequenced. PCR products were purified from 1.5\% agarose gels using QIA Quick Gel Extraction Kit (Qiagen, West Sussex, United Kingdom) and ligated into the TOPO-TA cloning vector and transformed into One Shot competent Escherichia coli (Invitrogen, Carlsbad, CA). The transformed cells were selected on Luria-Bertani (LB)-ampicillin agar plates and colonies were screened by PCR using vector primers T7 ( $5^{\prime}$-GTAATACGACTCACTATAGGGC-3') and T3 (5' -AATTAACCCTCACTAAAGGG$\left.3^{\prime}\right)$. The PCR products showing the expected insert size were sequenced in both orientations with dRhodamine terminators (Perkin-Elmer, Foster City, CA) on an ABI 377 DNA sequencer. ${ }^{24}$ At least 10 PCR clones from each sample were sequenced. The variable $(\mathrm{V})$, diversity $(\mathrm{D})$, and joining $(\mathrm{J})$ segments of the rearranged $\operatorname{IgH}$ genes were identified by sequence comparison to the Vbase using online DNAPLOT. ${ }^{25}$

\section{Results}

\section{Clinical features}

The clinical details are summarized in Table 1. Among the 6 children there were 4 females and 2 males between the ages of 3 and 11 years. Cases 1 to 4 presented with tonsillar enlargement with cases 2 and 3 showing bilateral tonsillar enlargement. All cases with tonsillar involvement underwent tonsillectomy, whereas the 2 cases with appendectal involvement underwent appendectomy. Case 2 underwent adenoidectomy 3 years after tonsillectomy. Despite the presence of histologic and immunohistochemical features suggestive of MZ lymphoma, especially light-chain restriction (see "Immunotypic features"), a diagnosis of atypical MZ hyperplasia was made in all patients and none received any further therapy. In 5 of the 6 cases where follow-up was available, the patients are alive and well with no evidence of lymphoma (mean follow-up 35.3 months).

\section{Histologic features}

The enlarged tonsils in cases 1 to 4 showed follicular hyperplasia and expansion of the MZ by centrocyte-like lymphocytes accompanied by many transformed blasts (Figure 1A-B). In the appendixes, the expanded MZ comprised mainly centrocyte-like cells with fewer transformed blasts (Figure 1C). Some of the follicles in 4 cases (cases 1 and 4-6) had a "moth-eaten" appearance reminiscent of progressive transformation of germinal centers and also consistent with follicular colonization by MZ cells (Figure 1C). All 4 cases with tonsillar involvement showed prominence of $\mathrm{B}$ cells within the tonsillar crypt epithelium (Figure 1B). In cases 5 and 6 there was focal invasion of the appendectal crypt epithelium reminiscent of lymphoepithelial lesions (Figure 1C, inset). The clinically normal tonsil that was available for examination in case 1 and the adenoids in case 2 , together with the control tonsils, showed only reactive follicular hyperplasia with no evidence of $\mathrm{MZ}$ expansion (Figure 2A).

\section{Immunophenotypic features}

In the 5 cases (cases 1-5) where material was available for detailed immunohistochemical examination, the MZ B cells, colonized follicles, and IEBCs/lymphoepithelial lesions had the identical immunophenotype. The cells expressed CD20, IRTA-1, CD43, CD21, IgM, IgD (weak), and BCL-2 and were negative for CD27, CD10, and MUM-1 (Figure 1D-F,H-I,M-N). All 6 cases showed a high-proliferation fraction (Figure $1 G$ ) and $\lambda$ light-chain restriction of the MZ, colonized follicles, and IEBCs (Figure 1J-L,O). Specific cytoplasmic and perinuclear space $\operatorname{Ig} \lambda$ staining of the MZ B cells and IEBCs and the absence of Igא staining in the same population, in the presence of a clearly polytypic mantle zone with clear perinuclear space staining, is strong evidence that the light-chain restriction observed is the result of Ig synthesis and not an artifact due to uptake of Ig from the environment. ${ }^{26}$ The plasma cells 


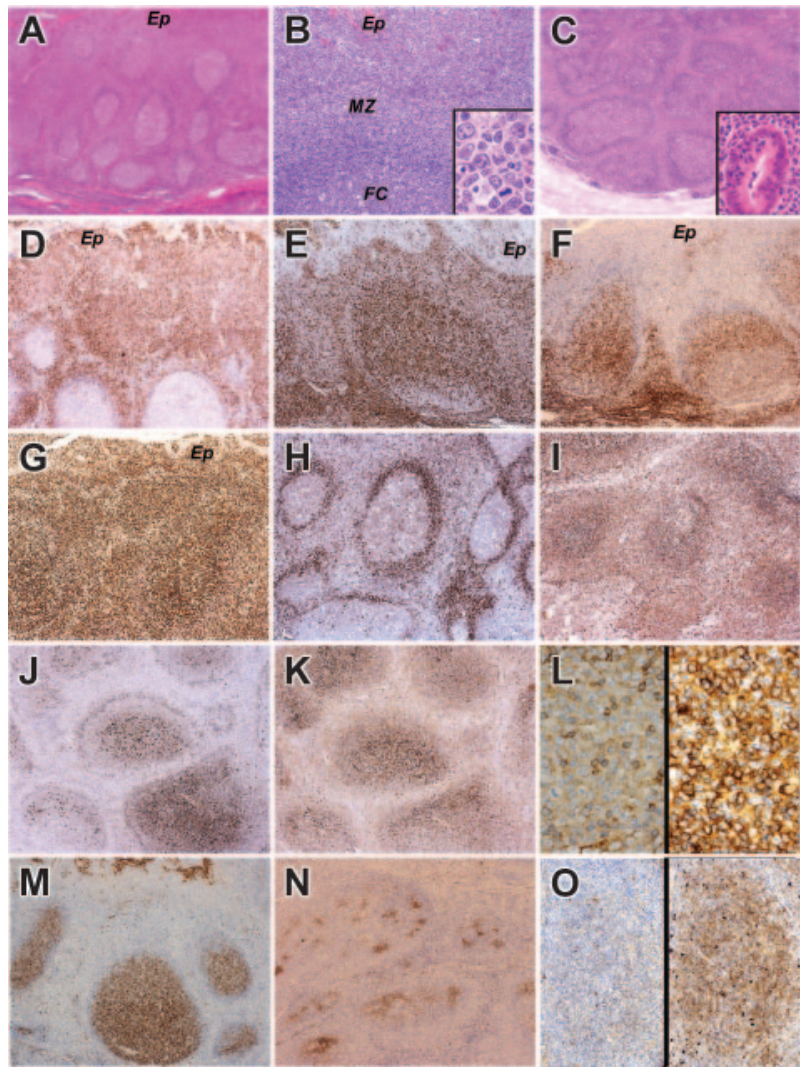

Figure 1. The histology and immunophenotype of MZ and IEBCs of the cases. Panels A, B, and D-M show the tonsil biopsy of case 2. Panel C shows the appendectal biopsy of case 5 . Panels $\mathrm{N}$ and $\mathrm{O}$ show the tonsil biopsy of case 4 . (A) Hematoxylin and eosin-stained sections of tonsil in case 2. There is widening of the MZs around hyperplastic follicles. (B) Higher magnification of MZ, adjacent crypt epithelium (Ep), mantle zone, and follicle center (FC). Inset shows cytologic detail of the $\mathrm{MZ}$ cells with transformed blasts. $(\mathrm{C})$ Hematoxylin and eosin-stained sections of the appendix in case 5 showing broadening of the MZs around hyperplastic B-cell follicles. The inset shows a crypt infiltrated by MZ lymphocytes. (D-F) The MZ and intraepithelial lymphocytes express IRTA-1 (D) and CD 43 (E) but fail to express CD27 (F). (G) The proliferation fraction shown by Ki 67 immunostaining is high. $(\mathrm{H}-\mathrm{I})$ The MZ cells show weak expression of $\operatorname{IgD}(\mathrm{H})$ and strong expression of $\lg M(\mathrm{I})$. (J-L) In contrast to the germinal center and follicular mantle, the MZ cells do not express $\lg \kappa$ light chain $(\mathrm{J})$ but do show strong expression of $\lg \lambda$ light chain $(\mathrm{K})$. (L) High magnification of MZ cells immunostained for $\kappa$ light chain (left) and $\lambda$ light chain (right). There is striking $\lambda$ light-chain restriction. Scattered small lymphocytes (probably residual mantle zone cells) express $\kappa$ light chain. (M-O) The follicle center cells in the tonsil biopsy of case 2 express CD10 (M), but in case 4 where the follicles are colonized by $\mathrm{MZ}$ cells, the $\mathrm{CD} 10^{+}$follicle centers are fragmented $(\mathrm{N})$. (O) The colonized areas of the follicles do not express $\kappa$ light chain (left) but show uniform expression of $\lambda$ light chain (right). Original magnifications, $\times 40(A, C) ; \times 200(B, O)$ $\times 1000$ (B inset); $\times 400$ (C inset, L); and $\times 100(D-K, M-N)$. Microscope, Olympus BX51; numerical aperture of objective lenses used: $\times 4,0.16 \mathrm{~mm}(\mathrm{~A}-\mathrm{C}) ; \times 10,0.40$ $\mathrm{mm}(\mathrm{D}-\mathrm{K}, \mathrm{M}-\mathrm{N}) ; \times 20,0.70 \mathrm{~mm}(\mathrm{~B}, \mathrm{O}) ; \times 40,0.85 \mathrm{~mm}(\mathrm{C}$ inset, $\mathrm{L})$; and $\times 100,0.95$ $\mathrm{mm}$ (B inset). Stains used: hematoxylin and eosin (A) and immunoperoxide (B-D). Camera, Olympus DP11 (Olympus, Tokyo, Japan); acquisition software, Adobe Reader 6.0 (Adobe, San Jose, CA); and software used for image processing, Adobe Photoshop 5.0.

present were polytypic and showed a similar pattern of heavy-chain expression ( $\operatorname{IgG}>\operatorname{IgA})$ in both cases and controls. Limited immunophenotyping of case 6 showed expression of CD20 and CD21 by the MZ cells. The normal (control) tonsillar IEBCs had the same immunophenotype as that of the cases, except for low expression of CD21 and expression of CD27 and polytypic immunoglobulin light chains. (Table 2; Figure 2B-D).

\section{Clonality and cellular origin of Ig $\lambda$-expressing B cells}

Results of molecular genetic analysis of cases and tonsillar control are summarized in Table 3. Control PCR showed good amplifica- tion of 100-, 200-, and 300-bp fragments in 5 of 6 cases and only 100- and 200-bp fragments in the remaining case, indicating that the quality of DNA extracted was adequate for the molecular tests performed, at least in the majority of cases studied. Despite $\operatorname{Ig} \lambda$ light-chain restriction shown by immunohistochemistry, analysis of DNA samples prepared from whole tissue sections by both heavy-chain (FR3-JH) and light-chain (FR3-JK and FR3-J $)$ PCR consistently showed a polyclonal pattern in all 6 cases. A polyclonal pattern was seen using FR2-JH and DH-JH PCR in 5 cases; the remaining case (case 6) showed no amplification due to poor DNA quality. The polyclonality of the $\operatorname{Ig} \lambda$-expressing B-cell population was further confirmed by analyses of the microdissected MZ and IEBCs in cases 2 and 3 using all the above PCR approaches (Figure 3). To examine the cellular origin of $\operatorname{Ig} \lambda$ expressing B cells, the FR2-JH PCR products from the microdissected MZ and IEBCs in cases 2 and 3 and the microdissected IEBCs in a reactive tonsil were cloned and sequenced. The details of somatic mutation and the usage of the $\mathrm{VH}$ family member of the heavy-chain gene are summarized in Table 4 . In both cases, the vast majority of the IEBCs and MZ cells showed that the rearranged $\mathrm{VH}$ gene was unmutated or mutated at a low frequency of less than $2 \%$, indistinguishable from the estimated replication error rate during PCR and cloning. ${ }^{27}$ In contrast, the intraepithelial B cells of the normal tonsil were somatically mutated $(>2 \%)$ in 7 of 9 clones. No common clone was found within the MZ, IEBCs, or between the 2 cell populations in the cases, confirming the polyclonal nature of the process. There was no biased usage of any $\mathrm{VH}$ family member or $\mathrm{DH}$ or JH segment.

Analysis of the $\operatorname{IgV} \lambda$ usage was attempted using a newly designed primer set to the FR2 and $\mathrm{J} \lambda$ regions. However, the FR2-J $\lambda$ PCR failed to show unbiased amplification from reactive tonsils and thus could not be reliably used for assessment of
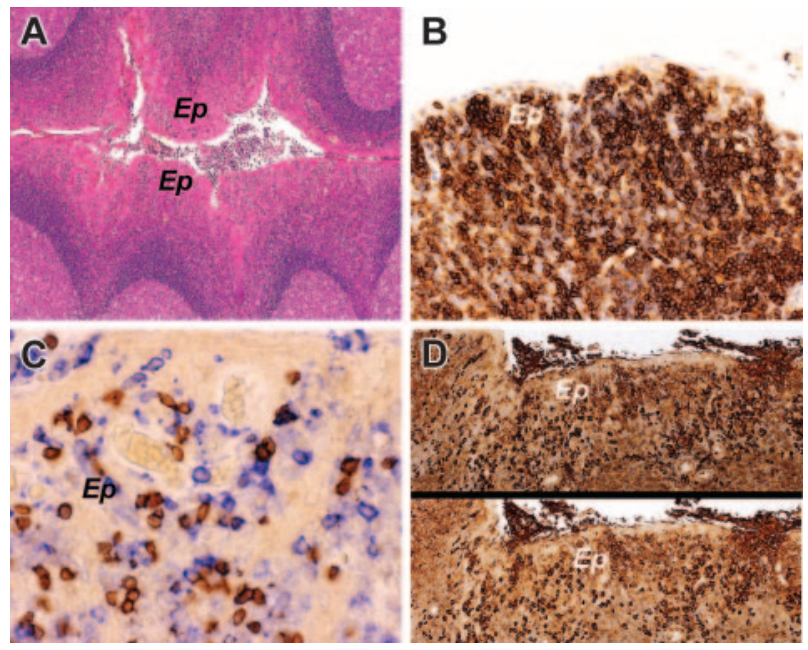

Figure 2. The histology and immunophenotypic characteristics of intraepithelial B cells in a control tonsil. (A) Control tonsil showing reactive follicular hyperplasia with no expansion of the MZ. The crypt epithelium (Ep) contains numerous intraepithelial lymphocytes. (B) CD27 immunostaining highlights expression by the intraepithelial $B$ cells. (C) Double immunostaining for CD3 in brown (DAB) and CD43 in blue (fast blue) shows many individual blue cells expressing CD43, but not CD3, consistent with intraepithelial B cells. (D) Crypt epithelium stained for $k$ immunoglobulin light chain (top) and $\lambda$ light chain (bottom). The intraepithelial $B$ cells are polytypic. Original magnifications, $\times 40(A) ; \times 200(B) ; \times 400(C)$; and $\times 100$ (D). Microscope, Olympus BX51; numerical aperture of objective lenses used: $\times 4,0.16$ $\mathrm{mm}(\mathrm{A}) ; \times 10,0.40 \mathrm{~mm}(\mathrm{D}) ; \times 20,0.70 \mathrm{~mm}(\mathrm{~B}) ; \times 40,0.85 \mathrm{~mm}(C)$. Stains used: hematoxylin and eosin (A) and immunoperoxide (B-D). Camera, Olympus DP11; acquisition software, Adobe Reader 6.0; and software used for image processing, Adobe Photoshop 5.0. 
From www.bloodjournal.org at UCL Library Services on August 22, 2008. For personal use only.

Table 2. Comparison of the immunophenotype of normal tonsillar IEBCs with the hyperplastic MZ B cells, colonized follicles, and IEBCs of the cases

\begin{tabular}{|c|c|c|c|c|c|c|c|c|c|}
\hline Immunohistochemistry & IRTA-1* & CD43* & CD21 & BCL-2* & CD27* & Ki 67 & $\lg M^{*}$ & $\lg D^{*}$ & Light chains \\
\hline Control tonsil IEBCs & + & + & $+($ weak $)$ & + & + & High & + & + & Polytypic \\
\hline $\begin{array}{l}\text { Cases showing MZ hyperplasia with MZ B } \\
\text { cells, colonized follicles, and IEBCs }\end{array}$ & + & + & + & + & - & High & + & + & $\lambda$ restricted \\
\hline
\end{tabular}

IEBCs indicates intraepithelial B cells; MZ, marginal zone; IRTA-1, immunoglobulin superfamily receptor translocated-associated 1; IgM, immunoglobulin M; IgD, immunoglobulin $\mathrm{D} ;+$, positive; and - , negative.

*Performed only on cases 1 to 5 . In case no. 6 , material was unavailable for detailed immunophenotyping.

V $\lambda$ usage in cases showing MZ hyperplasia. Nonetheless, none of the PCR clones sequenced from microdissected MZ and intraepithelial cells of cases 2 and 3 (10-17 clones per sample) showed somatic mutation in the rearranged $V \lambda$ (M.-Q.D., unpublished data, January 2004).

\section{Discussion}

Initially, the histologic and immunophenotypic features of the 6 cases described here strongly supported a diagnosis of MZ (MALT) lymphoma. The cells comprising the expanded MZs included numbers of transformed blasts, infiltrates of the tonsillar crypt and appendectal epithelium, and colonized reactive B-cell follicles, all features that have been documented as characteristic of MALT lymphoma. Immunophenotyping further supported a diagnosis of MALT lymphoma with aberrant expression of $\mathrm{CD} 43$ by $\mathrm{B}$ cells and, most importantly, $\operatorname{Ig} \lambda$ light-chain restriction. However, the high-proliferation fraction, expression of both $\mu$ and $\delta$ heavy chains, and absence of molecular evidence of Ig gene mutation (although only 2 cases were analyzed for this) all argue against a diagnosis of MALT lymphoma. Importantly, comprehensive molecular studies consistently failed to show any evidence of monoclonal Ig gene rearrangement in all 6 cases and, although clinical follow-up (mean 35.3 months) was relatively short, there has been no

Table 3. Results of molecular genetic analysis of cases and tonsillar control

\begin{tabular}{|c|c|c|c|c|c|}
\hline $\begin{array}{l}\text { Case no. or control and } \\
\text { nature of cells studied }\end{array}$ & FR2-JH & FR3-JH & DH-JH & Fr3-Jк & Fr3-J $\lambda$ \\
\hline \multicolumn{6}{|l|}{ Case 1} \\
\hline Whole section & $\mathrm{P}$ & $\mathrm{P}$ & $\mathrm{P}$ & $P$ & $\mathrm{P}$ \\
\hline \multicolumn{6}{|l|}{ Case 2} \\
\hline Whole section & $\mathrm{P}$ & $\mathrm{P}$ & $\mathrm{P}$ & $\mathrm{P}$ & $\mathrm{P}$ \\
\hline Microdissected MZ B cells & $P^{\star}$ & $\mathrm{P}$ & $\mathrm{P}$ & $P$ & $\mathrm{P}$ \\
\hline \multicolumn{6}{|l|}{ Case 3} \\
\hline Whole section & $\mathrm{P}$ & $\mathrm{P}$ & $\mathrm{P}$ & $\mathrm{P}$ & $\mathrm{P}$ \\
\hline Microdissected MZ B cells & $P^{\star}$ & $\mathrm{P}$ & $\mathrm{P}$ & $P$ & $\mathrm{P}$ \\
\hline \multicolumn{6}{|l|}{ Case 4} \\
\hline Whole section & $\mathrm{P}$ & $\mathrm{P}$ & $\mathrm{P}$ & $\mathrm{P}$ & $\mathrm{P}$ \\
\hline \multicolumn{6}{|l|}{ Case 5} \\
\hline Whole section & $\mathrm{P}$ & $\mathrm{P}$ & $\mathrm{P}$ & $\mathrm{P}$ & $\mathrm{P}$ \\
\hline \multicolumn{6}{|l|}{ Case 6} \\
\hline Whole section & Failed & $\mathrm{P}$ & Failed & $\mathrm{P}$ & $\mathrm{P}$ \\
\hline \multicolumn{6}{|l|}{ Control tonsil } \\
\hline Whole section & $\mathrm{P}$ & $\mathrm{P}$ & $\mathrm{P}$ & $P$ & $\mathrm{P}$ \\
\hline Microdissected IEBCs & $\mathrm{P} \dagger$ & $\mathrm{P}$ & $P$ & $P$ & $P$ \\
\hline
\end{tabular}

$\mathrm{P}$ indicates polyclonal; MZ, marginal zone; and IEBCs, intraepithelial B cells. ${ }^{*}$ Cloning and sequencing show germ line configuration of the rearranged IgVH gene.

†Cloning and sequencing show somatic mutation in the rearranged IgVH gene. evidence of clinical recurrence in any patient despite withholding lymphoma-directed therapy.

The sensitivity of PCR using $\mathrm{IgH}, \operatorname{Ig} \kappa$, and $\operatorname{Ig} \lambda$ BIOMED-2 primer sets as means of detecting clonality in B-cell proliferations exceeds $98 \% .^{23}$ It is therefore unlikely that the polyclonal result obtained in all 6 cases in our study represents a false-negative PCR. Furthermore, as expected with a CD27phenotype, the intraepithelial B cells and MZ cells microdissected in 2 of the cases lacked somatic mutations, which suggests that the amplification is representative of the expanded IEBCs and MZ.

In the study documenting MZ lymphoma in children and young adults, Taddesse-Heath et $\mathrm{al}^{13}$ reported its occurrence in the tonsil/adenoid in 3 children. In these 3 cases, all presenting with stage 1 disease, a histologic diagnosis of lymphoma was made on the basis of "aberrant" CD43 expression and/or $\operatorname{Ig} \lambda$ light-chain restriction. In the 2 cases in which PCR for $\mathrm{IgH}$ gene rearrangement was performed, the polyclonal result was interpreted as falsenegative. In light of our findings, these cases may well represent examples of this unusual $\mathrm{CD} 43^{+}, \operatorname{Ig} \lambda$ light-chain-restricted reactive proliferation rather than lymphoma.

The aberrant expression of the T-cell marker CD 43 by B cells is frequently interpreted as a marker of B-cell malignancy. CD43 is a T-cell lineage-associated antigen reported to be negative in the majority of nonneoplastic B cells, except plasma cells and rare lymphoplasmacytoid cells. It is expressed by most mantle cell lymphomas, small lymphocytic lymphomas, and Burkitt lymphomas. Ten percent to $20 \%$ of diffuse large B-cell

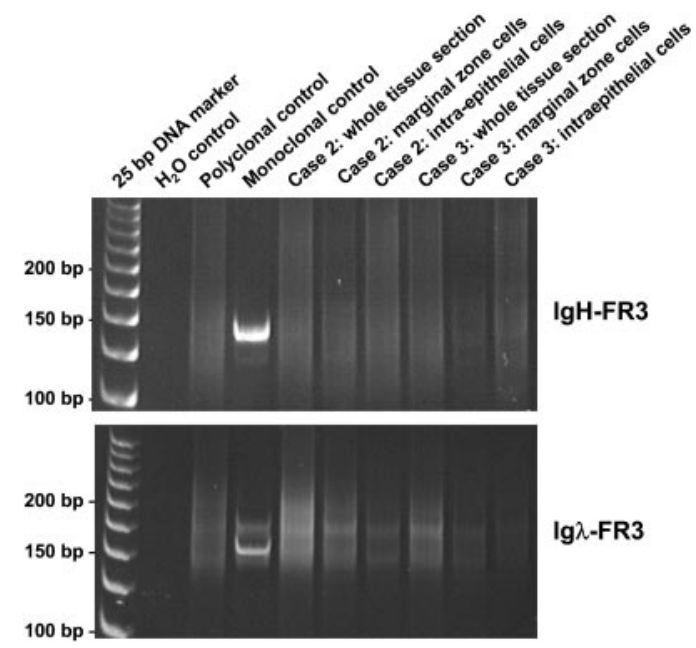

Figure 3. Analysis of PCR products of FR3 regions of $\lg \mathrm{H}$ and $\lg \lambda$ genes on polyacrylamide gels, in whole sections, and microdissected tissues of cases 2 and 3. PCR indicates polymerase chain reaction; FR3, framework 3 region; $\operatorname{lgH}$, immunoglobulin heavy chain; and $\lg \lambda$, immunoglobulin lambda light chain. 
From www.bloodjournal.org at UCL Library Services on August 22, 2008. For personal use only.

BLOOD, 15 NOVEMBER 2004 • VOLUME 104, NUMBER 10

Ig $\lambda$-RESTRICTED MARGINAL ZONE HYPERPLASIA OF MALT

Table 4. Comparison of IgH mutation in tonsillar intraepithelial B cells and atypical B cells of marginal zone hyperplasia

\begin{tabular}{|c|c|c|c|c|}
\hline $\begin{array}{l}\text { Lesion and type of } \\
\text { cells examined }\end{array}$ & $\begin{array}{l}\text { No. of PCR } \\
\text { clones studied }\end{array}$ & $\begin{array}{l}\text { No. of clones with } \\
\text { identical } \mathrm{VH}^{\star}\end{array}$ & $\begin{array}{l}\text { No. of clones with } \\
\text { identical CDR3 }\end{array}$ & $\begin{array}{l}\text { No. of clones showing somatic } \\
\text { mutation greater than } 2 \%(\%)\end{array}$ \\
\hline \multicolumn{5}{|l|}{ Control tonsil } \\
\hline Intraepithelial B cells & 9 & 2 (DP70) & 0 & $7(3-7)$ \\
\hline \multicolumn{5}{|l|}{ Case 2} \\
\hline MZ B cells & 10 & 2 (DP50) & 0 & 0 \\
\hline Intraepithelial B cells & 9 & 0 & 0 & $1(8.5)$ \\
\hline \multicolumn{5}{|l|}{ Case 3} \\
\hline MZ B cells & 9 & 0 & 0 & $1(4.9)$ \\
\hline Intraepithelial B cells & 10 & 2 (DP50) & 0 & $1(3.5)$ \\
\hline
\end{tabular}

VH indicates variable region, heavy chain; and CDR3, complementarity-determining region 3.

*VH family member used by the identical clone is indicated in parentheses.

lymphomas and $10 \%$ of follicular lymphomas have been reported to express CD43. Thus, when present in B-cell proliferations, CD43 expression is considered a fairly reliable marker of malignancy. ${ }^{18,28}$ Its wide usage in this capacity is in part due to the technical difficulties and problems of interpretation commonly encountered in immunoglobulin light-chain immunohistochemistry and the cost and lack of availability of molecular genetic studies for clonality analysis in routine diagnostic work. Clearly, in light of our findings, a degree of caution is warranted in interpreting CD43 expression.

In an attempt to ascertain which population of cells is expanded in this peculiar reactive process, we compared the immunophenotypic and molecular genetic characteristics with those of tonsillar IEBCs. These cells together with a component in the subepithelial region (Dono et $\mathrm{al}^{29-31}$ ) are thought to comprise the MZ B cells of the tonsil. Like the hyperplastic process that we describe, the tonsillar MZ B cells express IgM, IgD, CD21 (weakly), CD43, and IRTA-1 and have a high-proliferation fraction.

IRTA-1 is a surface B-cell receptor related to the Fc receptor and cell adhesion molecule families. ${ }^{31}$ Falini et al ${ }^{32}$ have shown that IRTA-1 expression in the tonsil and Peyer patches is confined to intraepithelial and subepithelial B cells. In sites of acquired MALT, such as the stomach, thyroid, and salivary gland, IRTA-1 is also expressed by intraepithelial MZ B cells. ${ }^{32}$ In MALT lymphoma, its expression is limited to tumor cells that form lymphoepithelial lesions. Their findings suggest that IRTA-1 expression is probably linked to epitheliotropism of B cells. ${ }^{33}$ The strong IRTA-1 expression by the lesional cells in our cases together with their expression of CD43 suggest that the cell of origin could be the intraepithelial (MZ) B cell of the tonsil or Peyer patch.

However, a major immunophenotypic discrepancy between the expanded MZ cells in our cases and the intraepithelial B cells of normal tonsils is CD27 expression by the latter. Dono et al, ${ }^{31}$ using flow cytometry, isolated 2 subsets of tonsillar subepithelial B cells, those with high CD27 expression and those with low expression, and found that they corresponded with mutated and unmutated B cells, respectively. CD27 expression is usually found on B cells with somatically mutated Ig genes. ${ }^{34,35}$ In the normal tonsil, the MZ B cells, like their counterparts in the dome region of the Peyer patches and the splenic MZ, are heterogeneous with regard to somatic mutations and comprise both mutated and unmutated cells. ${ }^{31,36,37}$ In our cases, the lesional cells were consistently CD27-. Moreover, genetic analysis showed that by contrast with the CD27+ $7^{+}$EBCs of the normal tonsil in which the Ig genes were mutated, the $\mathrm{Ig}$ genes of the expanded "MZ" B-cell population in our cases were in germ line configuration. The evidence in this study therefore suggests that it is the unmutated, $\mathrm{CD} 27^{-} \mathrm{MZ} \mathrm{B}$ cell that is the likely cell of origin in this peculiar hyperplastic condition. This would also explain the expression of CD43 as normal rather than "aberrant" and entirely consistent with a hyperplastic process.

Coexpression of $\operatorname{IgM}$ and $\operatorname{IgD}$, the pattern of heavy-chain expression characteristic of naive $\mathrm{B}$ cells, although observed in the unmutated $\mathrm{CD} 27^{-} \mathrm{B}$-cell proliferation in our cases, may not be a feature that is related to its "naive" genotype, as it is also the phenotype of predominantly mutated $\mathrm{CD} 27^{+}$IEBCs of normal tonsils.

There remains the question of Ig $\lambda$ light-chain restriction in all our cases. This might be explained by superantigen activation of the MZ B cells but our failure to show biased usage of any $\mathrm{IgVH}$ family member or IgH D segment is against the likelihood of this. The reason behind the preferential expansion of $\operatorname{Ig} \lambda$-expressing $\mathrm{B}$ cells remains unclear. The only previous documentation of such a phenomenon is in human herpesvirus 8 (HHV-8)-related Castleman disease and associated lymphoproliferative disorders, where Du et $\mathrm{al}^{27}$ showed polyclonal expansion of $\operatorname{Ig} \lambda$ light-chain-expressing $\mathrm{HHV}-8$-infected naive $\mathrm{B}$ cells. It raises the question of whether there is a functional difference between Ig $\mathrm{I}$ and $\operatorname{Ig} \lambda$ light-chain-expressing B cells.

In conclusion, we describe a hitherto unreported IRTA- $1^{+}$, $\mathrm{CD}_{4} 3^{+}, \mathrm{Ig} \lambda$ light-chain-restricted, polyclonal MZ B-cell proliferation in childhood. The diagnosis of this atypical MZ hyperplasia is challenging, both histologically and immunophenotypically, and can easily lead to an erroneous diagnosis of lymphoma.

\section{Acknowledgments}

We are grateful to Dr John Callaghan, Dr Eniko Bagdi, and Dr Claudio Doglioni for contributing cases to the study; Prof B. Falini for providing us with the M-IRTA-1 and MUM-1/IRF4 antibodies; Dr Hongtao Ye for technical assistance with microdissection; $\mathrm{Mr}$ Rifat A. Hamoudi and Dr Yuanping Zhou for assistance with sequencing; and Ms Kylie MacDonald for technical assistance with immunohistochemistry.

\section{References}

1. Miranda RN, Cousar JB, Hammer RD, Collins $\mathrm{RD}$, Vnencak-Jones CL. Somatic mutation analysis of $\mathrm{IgH}$ variable regions reveals that tumour cells of most parafollicular (monocytoid) B-cell lymphoma, splenic marginal zone B-cell lymphoma, and some hairy cell leukaemia are composed of memory B lymphocytes. Hum Pathol. 1999;30:306-312.
2. de Wolf-Peeters C, Pittaluga S, Dierlamm J, Wlodarska I, Van Den Berghe H. Marginal zone B-cell lymphomas including mucosa-associated lymphoid tissue type lymphoma (MALT), monocytoid 
B-cell lymphoma and splenic marginal zone cell lymphoma and their relation to the reactive marginal zone. Leuk Lymphoma. 1997;26:467-478.

3. Qin Y, Greiner A, Trunk MJ, Schmausser B, Ott MM, Muller Hermelink HK. Somatic hypermutation in low-grade mucosa-associated lymphoid tissue-type lymphoma. Blood. 1995;86:35283534.

4. Isaacson PG, Matutes E, Burke M, Catovsky D. The histopathology of splenic lymphoma with villous lymphocytes. Blood. 1994;84:3828-3834.

5. Isaacson $P G$, Piris MA. Splenic marginal zone lymphoma. Adv Anat Pathol. 1997;4:191-201.

6. Chacon JI, Mollejo M, Munoz E, et al. Splenic marginal zone lymphoma: clinical characteristics and prognostic factors of 60 patients. Blood. 2002;100:1648-1654.

7. Dogan A, Isaacson PG. Splenic marginal zone lymphoma. Semin Diagn Pathol. 2003;20:121127.

8. Isaacson PG, Wright DH. Malignant lymphoma of mucosa-associated lymphoid tissue: a distinctive type of B-cell lymphoma. Cancer 1983;52:14101416.

9. Isaacson PG, Muller-Hermelink HK, Piris MA, et al. Extranodal marginal zone B-cell lymphoma of mucosa-associated lymphoid tissue (MALT Iymphoma). In: Jaffe ES, Harris NL, Stein $\mathrm{H}$, et al, eds. World Health Organization Classification of Tumours: Pathology and Genetics of Tumours of Haematopoeitic and Lymphoid Tissues. Lyon, France: IARC Press; 2001:157-160.

10. Isaacson PG. Mucosa-associated lymphoid tissue lymphoma. Semin Hematol.1999;36:130147.

11. Wotherspoon AC, Ortiz-hidalgo C, Falzon MR, Isaacson PG. Helicobacter pylori-associated gastritis and primary B-cell gastric lymphoma. Lancet. 1991;338:1175-1176.

12. Hyjek E, Smith WJ, Isaacson PG. Primary B-cell lymphoma of salivary glands and its relationship to myoepithelial sialadenitis. Hum Pathol. 1988; 19:766-776.

13. Taddesse-Heath L, Pittaluga S, Lynn S, Bussey M, Raffeld M, Jaffe ES. Marginal zone B-cell lymphoma in children and young adults. Am J Surg Pathol. 2003:27:522-531.

14. Paulsen J, Lennert K. Low-grade B-cell lymphoma of mucosa-associated lymphoid tissue type in Waldeyer's ring. Histopathology. 1994;24: $1-11$
15. Menarguez J, Mollejo M, Carrion R et al. Waldeyer ring lymphomas: a clinicopathological study of 79 cases. Histopathology. 1994;24:9799.

16. Kojima M, Nakamura S, Shuimizu K, Itoh $\mathrm{H}, \mathrm{Ma}$ sawa N. Marginal zone B-cell lymphomas of Waldeyer's ring: a report of two tonsillectomy cases resembling histomorphological features of inflammatory lesions. Pathol Res Pract. 2001; 197:781-784

17. Lee JT, Paquette R, Sercarz JA, Wang MB. Mucosa-associated lymphoid tissue lymphoma of the lingual tonsil. Am J Otolaryngol. 2000;4:271 276.

18. Contos MJ, Kornstein MJ, Innes DJ, Ben-Ezra J The utility of CD20 and CD43 in subclassification of low-grade B-cell lymphomas on paraffin sections. Mod Pathol. 1992;5:631-633.

19. Ashton Key M, Jessup E, Isaacson PG. Immunoglobulin light chain staining in paraffin-embedded tissue using a heat mediated epitope retrieval method. Histopathology. 1996;29:525-531.

20. Dogan A, Bagdi E, Munson P, Isaacson PG. CD10 and BCL-6 expression in paraffin sections of normal lymphoid tissue and B-cell lymphomas. Am J Surg Pathol. 2000;24:846-852.

21. Koulis A, Diss T, Isaacson PG, Dogan A. Charac terisation of tumor-infiltrating T-lymphocytes in B-cell lymphomas of mucosa-associated lymphoid tissue. Am J Pathol. 1997;151:1353-1360.

22. Pan LX, Diss TC, Peng HZ, Isaacson PG. Clonality analysis of defined B-cell populations in archival tissue sections using microdissection and the polymerase chain reaction. Histopathology. 1994; 24:323-327.

23. van Dongen JJM, Langerak AW, Brüggemann $M$ et al. Design and standardization of PCR primers and protocols for detection of clonal immunoglobulin and T-cell receptor gene recombinations in suspect lymphoproliferations. Leukemia. 2003; 17:2257-2317.

24. Hamoudi R, Johnston S, Hutchinson G, D'Errico J. High throughput methods for gene identification, cloning and functional genomics using the genetic $G$ robotics workstation. JALA. 2002:5:53-59.

25. Medical Research Council Centre for Protein Engineering. Alignment to V BASE using DNAPLOT. http://www.mrc-cpe.cam.ac.uk/DNAPLOT.php? menu=901. Accessed December 2003

26. Isaacson P, Wright $\mathrm{DH}$, Judd MA, et al. The na ture of the immunoglobulin-containing cells in ma- lignant lymphoma: an immunoperoxidase study. J Histochem Cytochem. 1980;28:761-770.

27. Du MQ, Liu H, Diss TC, et al. Kaposi sarcomaassociated herpes virus infects monotypic $(\lg M \lambda)$ but polyclonal naïve B cells in Castleman disease and associated lymphoproliferative disorders. Blood. 2001;97:2130-2136.

28. Norton AJ, Isaacson PG. Detailed phenotypic analysis of B-cell lymphoma using a panel of antibodies reactive in routinely fixed wax-embedded tissue. Am J Pathol. 1987;128:225-240.

29. Dono M, Burgio VL, Tacchetti C, et al. Subepithelial B-cells in the human palatine tonsil, I: morphologic, cytochemical and phenotypic characterization. Immunol. 1996;26:2035-2042.

30. Dono M, Zupo S, Augliera A, et al. Subepithelial $B$-cells in the human palatine tonsil, II: functional characterization. Immunol. 1996;26:2043-2049.

31. Dono M, Zupo S, Leanza N, et al. Heterogeneity of tonsillar subepithelial B-lymphocytes, the splenic marginal zone equivalents. J Immunol. 2000;164:5596-5604

32. Falini B, Tiacci E, Pucciarini A, et al. Expression of IRTA-1 receptor identifies intraepithelial and subepithelial marginal zone $B$ cells of the mucosa-associated lymphoid tissue (MALT). Blood. 2003;102:3684-3692.

33. Miller I, Hatzivassilliou G, Cattoretti G, et al. IRTAs: a new family of immunoglobulin-like receptors differentially expressed in B-cells. Blood. 2002;99:2662-2669.

34. Klein U, Rajewsky K, Kuppers R. Human immunoglobulin (lg) M+ IgD + peripheral blood B cells expressing the CD27 surface antigen carry somatically mutated variable region genes: CD27 as a general marker for somatically mutated (memory) B cells. J Exp Med. 1998;188:1679 1689.

35. Jung J, Choe J, Li L, Choi YS. Regulation of CD27 expression in the course of germinal center B cell differentiation: the pivotal role of IL-10. Eur J Immunol. 2000;30:2437-2443.

36. Dunn-Walters DK, Isaacson PG, Spencer J. Sequence analysis of rearranged IgVH genes from microdissected human Peyer's patch marginal zone B cells. Immunology. 1996;88:618-624.

37. Tierens A, Delabie J, Michiels L, Vandenberghe P, De Wolf-Peeters C. Marginal-zone B cells in the human lymph node and spleen show somatic mutations and display clonal expansion. Blood. 1999;93:226-234. 